\title{
SUSTAINABILITY AND THE CONCEPT OF SHARED VALUE AND THE 4TH INDUSTRIAL REVOLUTION: A BIBLIOMETRIC ANALYSIS OF TWO SCIENTIFIC NETWORKS
}

\author{
I. de Wet ${ }^{1} \&$ I.H. de Kock ${ }^{1 *}$
}

\section{ARTICLE INFO}

\section{Article details \\ Presented at the $32^{\text {nd }}$ annual conference of the Southern African Institute for Industrial Engineering (SAIIE), held from 4-6 October 2021 in Muldersdrift, South Africa. \\ Available online \\ 29 Nov 2021 \\ Contact details \\ Corresponding author \\ imkedk@sun.ac.za \\ Author affiliations \\ 1 Department of Industrial \\ Engineering, University of Stellenbosch, South Africa \\ ORCID® identifiers \\ I. de Wet \\ https://orcid.org/0000-0002-8712-9565 \\ I.H. de Kock \\ https://orcid.org/0000-0003-4136-7418}

\section{DOI}

http://dx.doi.org/10.7166/32-3-2609

\section{ABSTRACT}

The role of the technologies, concepts, and philosophies associated with the Fourth Industrial Revolution (4IR) has been argued to hold significant value in the quest for sustainability. Furthermore, the concept of 'shared value' has been put forward as an approach that holds significant value when aiming to bring about socially just, economically fair, and environmentally friendly production and consumption practices. The importance of the link between the concept of shared value and $4 I R$ is explored in this paper using bibliometric analysis, and we expose the different structures of these fields, including keywords, key authors, and the coherence of these two scientific networks in order to uncover areas of integration between them. The findings of this analysis indicate that a clear gap in integration exists; and the opportunity for research in this field could further contribute to the debate on using innovative, contemporary technologies - such as those associated with 4IR - to support approaches to ensure increasingly sustainable business practices, such as shared value.

\section{OPSOMMING}

Die rol van die tegnologieë, konsepte en filosofieë wat betrekking het tot die Vierde Industriële Revolusie (4IR) mag noemenswaardige waarde inhou vir die bevordering van volhoubaarheid. Die konsep van 'gedeelde waarde' word geag as ' $n$ volhoubare besigheidsbenadering wat sosiaal regverdige, ekonomies billike en omgewingsvriendelike produksie- en verbruikspraktyke kan bewerkstellig. Die waarde van die korrelasie tussen die konsep van gedeelde waarde en 4IR word in hierdie navorsing ondersoek deur die gebruik van bibliometriese analise. Die verskillende strukture van hierdie konsepte word ten toon gestel, insluitend sleutelwoorde, sleutelouteurs en die skakel tussen hierdie twee wetenskaplike netwerke om enige areas van integrasie te identifiseer. Die bevindinge van hierdie analise dui aan dat daar 'n duidelike gaping in die integrasie van die konsepte bestaan. Daar is dus die geleentheid vir navorsing in hierdie veld wat verder kan bydra tot die debat oor die gebruik van innoverende, kontemporêre tegnologieë - soos dié wat met 4IR geassosieer word - om benaderings te ondersteun om toenemend volhoubare sakepraktyke (soos gedeelde waarde) te verseker.

\section{INTRODUCTION: CORPORATE SHARED VALUE AND THE 4IR}

The Fourth Industrial Revolution (4IR) is a technological transformation that will radically change how we live, function, and interact with one another. Klaus Schwab has described the transition as unlike anything humanity has seen before "in terms of scale, scope, and complexity" [1]. Some examples of the areas in which 4IR is revolutionising the way humans live are artificial intelligence (Al) robotics, machine learning, nanotechnology, biotechnology, quantum computing, blockchain, the Internet of Things (IoT), and 3D printing [2]. The 4IR is also referred to as 'Industry 4.0', a term that was coined in Germany in 2011 [3]. These technologies have significant implications for the conceptualisation and enjoyment of human rights [2]. They also raise concerns about issues of power asymmetry, security, and the resulting threats of inequality, disempowerment, and exploitation [2]. 4IR will allow businesses to reuse resources and assets, as well as repurpose energy for further use, reducing emissions and resource loads. Owing to various 
technological advancements, 'greener machines' are enabling organisational success in meeting environmental standards and regulations [2]. According to Schwab, 4IR has the ability to create sustainable, socially inclusive, and resource-secure economies, and to improve global environmental sustainability and governance - "a crucial human rights goal" [4].

Companies have rarely seen themselves as drivers of social reform in the past [5]. The credibility of industry has been severely questioned, with businesses seen to be prospering to the detriment of the greater community [6]. Nonetheless, the interconnection between and interdependence of social change and business growth is becoming clearer. Poverty, waste, and illness would decrease if industry could stimulate social change in every part of the world, while corporate income would increase [5]. Pursuing financial success in a way that also creates societal benefits (also referred to as 'creating shared value' (CSV) - a term coined by Kramer and Porter in 2011 [6]) has become an imperative for corporations in recent times. At the same time, many of the world's challenges, from income inequality to climate change, are so broad that solutions require the benefits of the private sector's experience and scalable business models [5]. There have been many business sustainability movements (BSMs), including corporate social responsibility (CSR), Society 5.0, the circular economy (CE), and the sharing economy (SE) [7]. These movements share important similarities with CSV.

This paper aims to establish the extent of either integration or disconnection between the concepts of 4IR and CSV in order to elucidate the level and extent to which these bodies of literature have been integrated. Bibliometric and content analyses are performed to confirm or refute the disconnect between the literature pertaining to the 4IR and that pertaining to CSV. Bibliometrics is a technique for standardising and analysing data from a variety of sources [8]. The term 'bibliometric analysis' refers to the process of summarising the most representative findings of a collection of bibliographic data [9]. This paper uses bibliometric analysis to provide an overview of current research on the use of 4IR technology for CSV as a way to determine the present trends and potential research directions. This research effort aims to contribute to a better understanding of the current literature by addressing the following research questions:

1. How is the current research being conducted on 4IR and CSV respectively?

2. What is the extent of either integration or disconnection between the concepts of the 4IR and CSV, and what is the level and extent to which these bodies of literature have been integrated?

3. How has the application of 4IR technological interventions in shared value business practices evolved?

4. What are the underlying themes of research into the technological interventions in sustainable business practices related to shared value?

a. What external factors have influenced the evolution and expansion of academic works in the fields of $4 I R$ and CSV research?

b. Does an underlying framework for the use of 4IR technology in CSV exist?

5. What should be the direction of future research in this domain?

Given the significance of 4IR technology and its implementation in CSV business practices in addressing the grand challenges, further research efforts through these bodies of expertise are expected to allow a just transition to sustainability.

The structure of the paper is as follows. Section 2 describes the methodology of bibliometric analysis that was conducted. The next section presents the bibliometric analysis and the statistics pertaining to the analysis, followed by a discussion of the results.

\section{METHODOLOGY}

The method described by Zupir and Cater [10] of the methodology of bibliometric analysis includes these five essential stages: "design of a research, preparation of a sample of articles, presentation of the data, analysis of the data, and presentation and interpretation of the results". The review methodology for this paper is described in Figure 1.

The design of this research is based on the research questions posed above. The preparation of sample articles starts with the selection of keywords. To place 4IR technologies and shared value in context, as well as the challenges that these two areas of research face, to reinforce the rationale of this study from theoretical and practical perspectives, both domains were separately researched to conduct the bibliometric analysis. 
There are, however, several limitations to be considered. The information presented in this paper provides only a general orientation to these two domains with respect to the various dimensions that have been analysed. There are also many other databases that were not considered for the use of this paper that might contain information that would be relevant and important to this paper. An effort has been made to consider more than one database.

Two databases were considered: SCOPUS and Web of Science (WOS). After thorough investigation, it was decided that SCOPUS would be used to collect the data to use in this study because (1) it is easy to use; (2) the multidisciplinary aspect allows researchers to search easily outside their discipline [11]; (3) the number of search results for the specific field of study was higher than that for WOS; (4) the R-studio bibliometrix package supports SCOPUS data [12]; and (5) it is easy to export 2000 results at once.

Concerning CSV: As the CSV concept is mostly referred to as 'shared value', this phrase was used as a direct match search for article title, abstract, and keywords in the SCOPUS database. The search returned 825 results between the years 2011 and 2021.

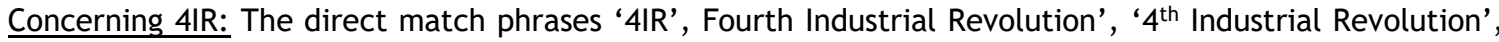
'Industry 4.0', and ' 14.0 ' for article title, abstract, and keywords were included in the search of SCOPUS between the years 2011 and 2021. The search returned 17891 documents. These phrase combinations were used in all searches when referring to 4IR.

Integration of concepts: Given the objective of this research, the role of 4IR technology applications in shared value business practices needed to be investigated. Thus, in order to focus on 4IR technological interventions in CSV, another string was researched: 'shared value' and '4IR' or 'Fourth Industrial Revolution' or ' 4 th Industrial Revolution' or 'Industry 4.0' or '14.0'. The final search string in SCOPUS resulted in four articles. In this sample, all of the articles were related to the topic under investigation. An overview is given of the academic literature on Industry 4.0 about other business sustainability movements that have been considered, to deduce whether there has been more or less research conducted in this regard.

Table 1 depicts a variety of searches done in the SCOPUS database, with different labels to denote the variety of searches. Different keywords were identified in section 2, and different combinations of these keywords were used in the different searches. If a keyword was used in a search, it is marked with an ' $x$ '. In total, 10 different categories of searches were identified. The keywords are split into two sections: those that fall into the business sustainability movements, and those that pertain to the 4IR. The keywords for $4 I R$ always include all five identified variations.

Table 1: Search combinations and categories

\begin{tabular}{|c|c|c|c|c|c|c|c|c|c|c|}
\hline \multirow[b]{2}{*}{ Keywords } & \multicolumn{10}{|c|}{ Labels of categories of searches } \\
\hline & $\{\mathrm{SV}\}$ & 4IR & $\{S V\}_{-} 4 \mathrm{IR}$ & SV_4IR & CSV_4IR & CSR_4IR & S5.0_4IR & CE_4IR & SE_4IR & All_4IR \\
\hline $\begin{array}{l}\text { Shared value } \\
\text { (direct match) }\end{array}$ & $x$ & & $x$ & $x$ & & & & & & $x$ \\
\hline $\begin{array}{l}\text { Corporate } \\
\text { shared value / } \\
\text { Creating } \\
\text { shared value }\end{array}$ & & & & $\mathbf{x}$ & $x$ & & & & & $x$ \\
\hline $\begin{array}{l}\text { Corporate } \\
\text { social } \\
\text { responsibility }\end{array}$ & & & & & & $\mathbf{x}$ & & & & $x$ \\
\hline Society 5.0 & & & & & & & $\mathbf{x}$ & & & $\mathbf{x}$ \\
\hline $\begin{array}{l}\text { Circular } \\
\text { economy }\end{array}$ & & & & & & & & $\mathbf{x}$ & & $x$ \\
\hline $\begin{array}{l}\text { Sharing } \\
\text { economy }\end{array}$ & & & & & & & & & $x$ & $x$ \\
\hline \multicolumn{11}{|l|}{ AND } \\
\hline $4 I R$ & & $x$ & $x$ & $\mathrm{x}$ & $x$ & $x$ & $\mathrm{x}$ & $x$ & $\mathrm{x}$ & $x$ \\
\hline
\end{tabular}


Review methodology: The review methodology was followed in full, as described in Figure 1: Review methodology (adapted from [13])in only three of the categories: - $\{\mathrm{SV}\}, 4 \mathrm{R}$, and $\{\mathrm{SV}\}\}_{-} 4 \mathrm{R}$. This was decided because of the exclusion of irrelevant information. The Biblioshiny app for the Bibliometrix r-package [12] and the SCOPUS analysis tool were used to gather results. The data gathered from other BSMs was gathered and used only to compare the number of articles written on these various fields of study.

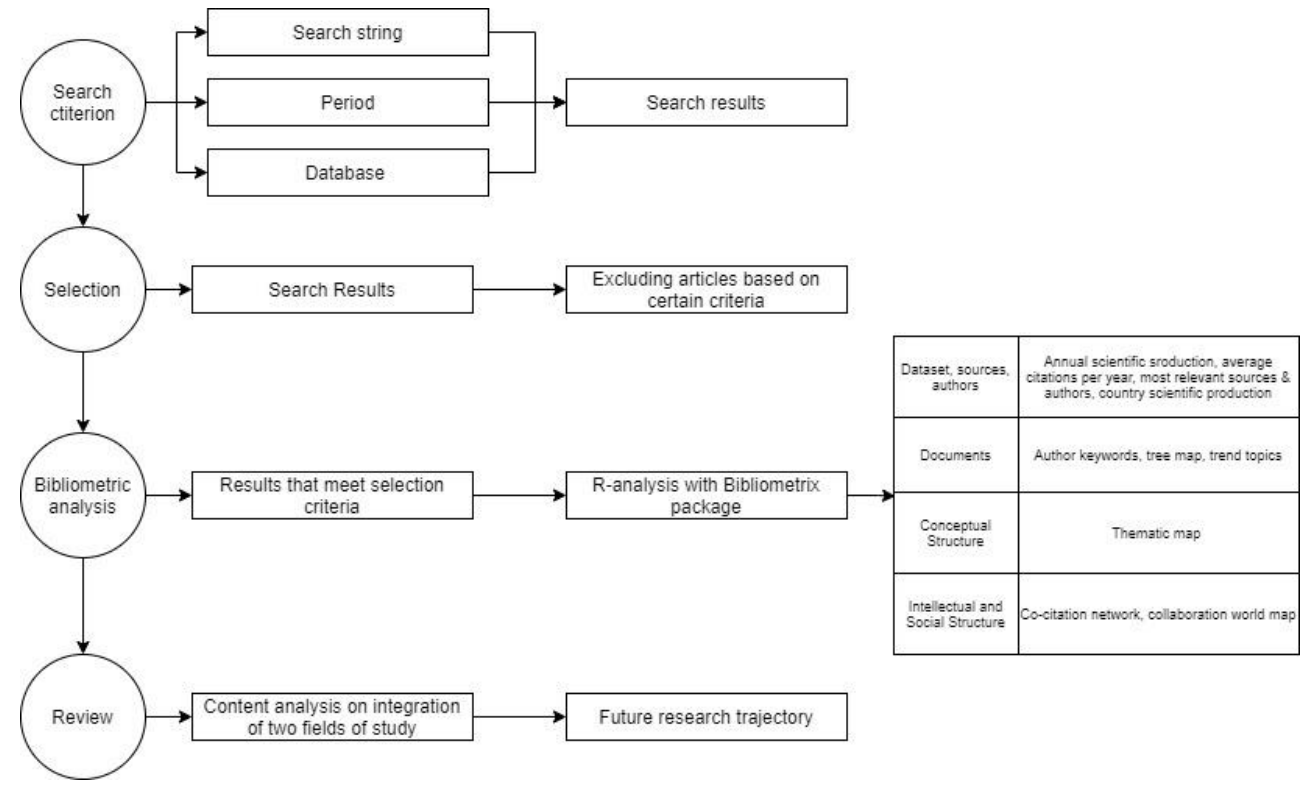

Figure 1: Review methodology (adapted from [13])

After designing the research phase, the second stage involved the application of an open-source statistical software, R Studio, with the Bibliometrix package to carry out a bibliometric analysis of the aggregated sample articles. The analysis and subsequent stages are detailed in the next sections.

\section{BIBLIOMETRIC ANALYSIS (BA)}

The results obtained from the SCOPUS search are detailed in this section. For a comprehensive analysis, no exclusion or inclusion criteria except the date range (2011-2021) were used in the initial search in order to have as much literature as possible. Section 3.1 presents the overall search results and their analysis and inferences. Then section 3.2 focuses on the literature within the integrated concept of CSV and 4IR.

\subsection{Basic search results}

Table 2 displays the search algorithms and the resulting document numbers from the prescribed search categories.

Table 2: Search results

\begin{tabular}{|c|c|c|c|}
\hline & $\begin{array}{l}\text { Search } \\
\text { category } \\
\text { label }\end{array}$ & SCOPUS algorithm & $\begin{array}{l}\text { Number of } \\
\text { documents } \\
\text { obtained }\end{array}$ \\
\hline 1 & $\{\mathrm{SV}\}$ & TITLE-ABS-KEY ( $\{$ Shared Value $\}$ ) AND PUBYEAR > 2010 & 825 \\
\hline 2 & $4 \mathrm{IR}$ & $\begin{array}{l}\text { ( TITLE-ABS-KEY }(\{4 I R\}) \text { OR TITLE-ABS-KEY ( \{Fourth Industrial Revolution }\}) \\
\text { OR TITLE-ABS-KEY }(\{4 \text { th Industrial Revolution }\}) \text { OR TITLE-ABS-KEY ( } \text { Industry } \\
\text { 4.0\}) OR TITLE-ABS-KEY }(\{14.0\})) \text { AND PUBYEAR }>2010\end{array}$ & 17891 \\
\hline 3 & $\{S V\}_{-} 4 \mathrm{IR}$ & $\begin{array}{l}\text { ( TITLE-ABS-KEY ( }\{\text { Shared Value }\}) \text { AND TITLE-ABS-KEY ( }\{4 \text { IR }\}) \text { OR TITLE- } \\
\text { ABS-KEY ( \{Fourth Industrial Revolution }\}) \text { OR TITLE-ABS-KEY ( }\{4 \text { th Industrial } \\
\text { Revolution }\} \text { ) OR TITLE-ABS-KEY ( \{lndustry } 4.0\}) \text { OR TITLE-ABS-KEY }(\{14.0\}) \\
\text { ) AND PUBYEAR > } 2010\end{array}$ & 4 \\
\hline
\end{tabular}




\begin{tabular}{|c|c|c|c|}
\hline & $\begin{array}{l}\text { Search } \\
\text { category } \\
\text { label }\end{array}$ & SCOPUS algorithm & $\begin{array}{l}\text { Number of } \\
\text { documents } \\
\text { obtained }\end{array}$ \\
\hline 4 & SV_4IR & $\begin{array}{l}\text { ( TITLE-ABS-KEY ( }\{4 I R\}) \text { OR TITLE-ABS-KEY ( \{Fourth Industrial Revolution }\} \text { ) } \\
\text { OR TITLE-ABS-KEY ( }\{4 \text { th Industrial Revolution }\}) \text { OR TITLE-ABS-KEY ( }\{\text { Industry } \\
\text { 4.0\}) OR TITLE-ABS-KEY ( }\{14.0\}) \text { AND TITLE-ABS-KEY ( }\{\text { Shared Value }\}) \text { OR } \\
\text { TITLE-ABS-KEY (corporate AND shared AND value ) OR TITLE-ABS-KEY ( } \\
\text { creating AND shared AND value ) ) AND PUBYEAR > } 2010\end{array}$ & 12 \\
\hline 5 & CSV_4IR & $\begin{array}{l}\text { ( TITLE-ABS-KEY ( corporate AND shared AND value ) OR TITLE-ABS-KEY ( } \\
\text { creating AND shared AND value ) AND TITLE-ABS-KEY }(\{4 \text { IR\}) OR TITLE-ABS- } \\
\text { KEY (\{Fourth Industrial Revolution\}) OR TITLE-ABS-KEY }(\{\text { Industry } 4.0\}) \text { ) } \\
\text { AND PUBYEAR }>2010\end{array}$ & 10 \\
\hline 6 & CSR_4IR & $\begin{array}{l}\text { TITLE-ABS-KEY ( }\{4 \text { IIR }\}) \text { OR TITLE-ABS-KEY ( \{Fourth Industrial Revolution }\}) \\
\text { OR TITLE-ABS-KEY ( }\{4 \text { th Industrial Revolution }\}) \text { OR TITLE-ABS-KEY ( \{lndustry } \\
\text { 4.0\}) OR TITLE-ABS-KEY ( \{14.0\}) AND TITLE-ABS-KEY ( \{Corporate Social } \\
\text { Responsibility\}) ) AND PUBYEAR > } 2010\end{array}$ & 27 \\
\hline 7 & S5.0_4IR & $\begin{array}{l}\text { ( TITLE-ABS-KEY ( }\{4 I R\}) \text { OR TITLE-ABS-KEY ( \{Fourth Industrial Revolution }\} \text { ) } \\
\text { OR TITLE-ABS-KEY }(\{4 \text { th Industrial Revolution }\}) \text { OR TITLE-ABS-KEY ( \{lndustry } \\
\text { 4.0\}) OR TITLE-ABS-KEY }(\{14.0\}) \text { AND TITLE-ABS-KEY ( \{Society } 5.0\}) \text { OR } \\
\text { TITLE-ABS-KEY }(\{S 5.0\})) \text { AND PUBYEAR }>2010\end{array}$ & 54 \\
\hline 8 & CE_4IR & $\begin{array}{l}\text { ( TITLE-ABS-KEY ( }\{4 I R\}) \text { OR TITLE-ABS-KEY ( \{Fourth Industrial Revolution }\} \text { ) } \\
\text { OR TITLE-ABS-KEY ( }\{4 \text { th Industrial Revolution }\}) \text { OR TITLE-ABS-KEY ( \{Industry } \\
\text { 4.0\}) OR TITLE-ABS-KEY ( }\{14.0\}) \text { AND TITLE-ABS-KEY ( \{Circular Economy }\}) \\
\text { ) AND PUBYEAR > } 2010\end{array}$ & 185 \\
\hline 9 & SE_4IR & $\begin{array}{l}\text { ( TITLE-ABS-KEY ( }\{4 I R\}) \text { OR TITLE-ABS-KEY ( \{Fourth Industrial Revolution }\}) \\
\text { OR TITLE-ABS-KEY ( }\{4 \text { th Industrial Revolution\} ) OR TITLE-ABS-KEY ( \{Industry } \\
4.0\}) \text { OR TITLE-ABS-KEY }(\{14.0\}) \text { AND TITLE-ABS-KEY (\{Sharing Economy }\})) \\
\text { AND PUBYEAR }>2010\end{array}$ & 35 \\
\hline
\end{tabular}

\subsubsection{Bibliometric statistics (descriptive)}

The bibliometric statistics for the categories of $\{\mathrm{SV}\}, 4 I \mathrm{R}$ and $\{\mathrm{SV}\} \_4 I \mathrm{R}$ were analysed through the open source statistical software, Biblioshiny for the Bibliometrix $r$-package, to gather results [12]. After careful consideration following the review methodology, it was decided to analyse only the categories of SV, 4IR and $\{\mathrm{SV}\}_{-} 4 \mathrm{IR}$, as these were the most relevant academic literature after excluding certain literature that did not meet the criteria.

The statistical summary of the data is given in Table 3, discussing the basic bibliometric statistics of the dataset, including the most prominent document types, document content, and author and author collaboration statistics. The relatively small discrepancy in figures between the keyword 'plus' (i.e., terms often appearing in titles) and the authors' keywords indicates the accuracy of the search criteria. An interesting indicator is the collaboration index $(\mathrm{Cl})$, which gives the ratio of the number of authors in the articles that have more than one author and the number of articles that have more than one author [7], which was calculated for $\{\mathrm{SV}\}, 4 I \mathrm{R}$ and the integrated concept $\left(\{\mathrm{SV}\} \_4 \mathrm{IR}\right)$ to be $2.67,2.35$, and 3 respectively. This shows that, on average, every document published in this field has three authors, indicating the presence of a strong collaborative network in these fields of study.

Table 3: Statistical summary of data

\begin{tabular}{|c|c|c|c|}
\hline & SV $(\{S V\})$ & 4IR & Integrated concept (\{SV $\left.\} \_4 I R\right\}$ \\
\hline Description & \multicolumn{3}{|l|}{ Results } \\
\hline Time span & 2011:2021 & 2011:2021 & 2019:2020 \\
\hline Sources (journals, books, etc) & 568 & 3951 & 4 \\
\hline Documents & 825 & 17891 & 4 \\
\hline Average years from publication & 4.02 & 1.92 & 1.25 \\
\hline Average citations per documents & 12.33 & 6.659 & 0.5 \\
\hline Average citations per year per doc & 1.888 & 1.838 & 0.1667 \\
\hline
\end{tabular}




\begin{tabular}{|c|c|c|c|}
\hline \multirow[b]{2}{*}{ Description } & SV $(\{S V\})$ & 4IR & Integrated concept ( $\left.\{\mathrm{SV}\} \_4 \mathrm{IR}\right\}$ \\
\hline & \multicolumn{3}{|l|}{ Results } \\
\hline References & 42243 & 536065 & 134 \\
\hline \multicolumn{4}{|l|}{ DOCUMENT TYPES } \\
\hline Article & 560 & 6282 & 3 \\
\hline Book chapter & 90 & 808 & - \\
\hline Conference paper & 96 & 9400 & 1 \\
\hline Conference review & 5 & 361 & - \\
\hline Review & 44 & 632 & - \\
\hline \multicolumn{4}{|l|}{ DOCUMENT CONTENTS } \\
\hline Keywords plus (ID) & 1995 & 38906 & 9 \\
\hline Author's keywords (DE) & 2275 & 30767 & 18 \\
\hline \multicolumn{4}{|l|}{ AUTHORS } \\
\hline Authors & 1773 & 37813 & 8 \\
\hline Author appearances & 1982 & 61411 & 8 \\
\hline Authors of single-authored documents & 224 & 1865 & 2 \\
\hline Authors of multi-authored documents & 1549 & 35948 & 6 \\
\hline \multicolumn{4}{|l|}{ AUTHORS COLLABORATION } \\
\hline Single-authored documents & 244 & 2594 & 2 \\
\hline Documents per author & 0.465 & 0.473 & 0.5 \\
\hline Authors per document & 2.15 & 2.11 & 2 \\
\hline Co-authors per document & 2.4 & 3.43 & 2 \\
\hline Collaboration index & 2.67 & 2.35 & 3 \\
\hline
\end{tabular}

\subsubsection{Annual scientific production}

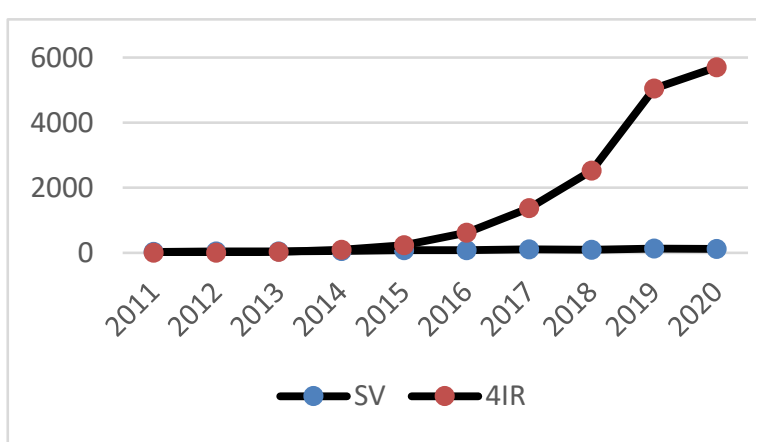

Figure 2: Annual scientific production for SV \& 4IR (2011-2020)

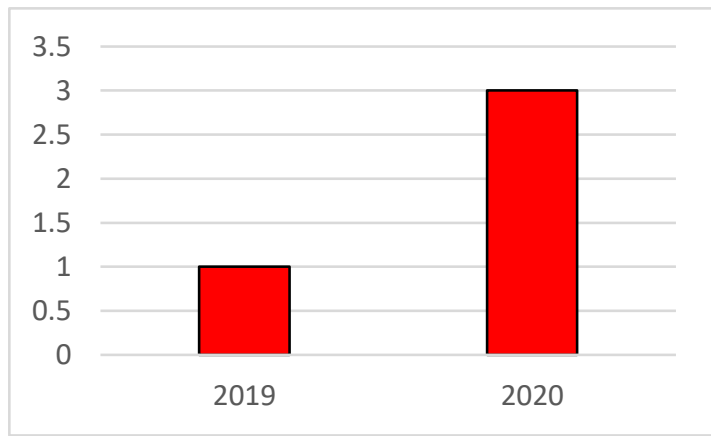

Figure 3: Annual scientific production for integrated concept (all time)

Figure 2 and Figure 3 represent the list of the annual scientific productions from 2011 to 2020 (only full years were included). SV and 4IR have grown steadily since 2011, with the academic literature written on 4IR increasing exponentially (much more so than SV). 4IR has only had consistent literature output since 2011, even if the concept was first considered much earlier. The high rate of publication can be attributed to the exponential increase in the 4IR technologies that were developed.

The focus on business sustainability and 4IR has only become a priority more recently, as it was only in 2019 that literature appeared on the integrated concept of SV and 4IR. The document count increased from one 
document to three in 2020. Even with this increase, there is a clear gap in the literature that studies the application of 4IR technologies to SV business concepts, with only four publications on the subject.

\subsubsection{Prominent sources of publication}

The most prominent sources of publication can be seen in Table 4. It can be observed that Sustainability Switzerland is a prominent source for both SV and 4IR. The majority of the most prominent sources of publication for SV promote research into sustainable practices, which is a major focus point of SV. For 4IR, more technical engineering sources are observed, which makes sense because of the new technologies being developed. For the integrated concepts, the primary aim of the journal ICIC Express Letters Part B: Application is to publish "quality short papers of new developments and trends, novel techniques and approaches, innovative methodologies and technologies on the theory and applications of intelligent systems, information and control" [14]. The other three sources can also be described as sources that advance sustainable practices from a technological viewpoint.

Table 4: Ten most prominent sources of publication

\begin{tabular}{|c|c|c|c|c|c|}
\hline \multicolumn{2}{|l|}{ SV $(\{S V\})$} & \multicolumn{2}{|l|}{ 4IR } & \multicolumn{2}{|c|}{ Integrated concept (\{SV\}_4IR\} } \\
\hline Sources & Articles & Sources & Articles & Sources & Articles \\
\hline $\begin{array}{l}\text { Sustainability } \\
\text { Switzerland }\end{array}$ & 33 & Procedia Computer Science & 554 & $\begin{array}{l}\text { ICIC Express Letters Part } \\
\text { B: Applications }\end{array}$ & 1 \\
\hline $\begin{array}{l}\text { Journal of Business } \\
\text { Ethics }\end{array}$ & 19 & $\begin{array}{l}\text { Advances in Intelligent } \\
\text { Systems and Computing }\end{array}$ & 359 & Industria & 1 \\
\hline Ethical Economy & 10 & Procedia CIRP & 334 & $\begin{array}{l}\text { International Journal of } \\
\text { Quality and Service } \\
\text { Sciences }\end{array}$ & 1 \\
\hline $\begin{array}{l}\text { Journal of Cleaner } \\
\text { Production }\end{array}$ & 10 & $\begin{array}{l}\text { IOP Conference Series } \\
\text { Materials Science and } \\
\text { Engineering }\end{array}$ & 317 & $\begin{array}{l}\text { Digital World and Industry } \\
\text { X.0 - The 29th } \\
\text { International Conference } \\
\text { of the International } \\
\text { Association for } \\
\text { Management of } \\
\text { Technology IAMOT } 2020\end{array}$ & 1 \\
\hline $\begin{array}{l}\text { Corporate Social } \\
\text { Responsibility and } \\
\text { Environmental } \\
\text { Management }\end{array}$ & 8 & $\begin{array}{l}\text { Lecture notes on computer } \\
\text { science, including sub- } \\
\text { series lecture notes on } \\
\text { artificial intelligence and } \\
\text { lecture notes on } \\
\text { bioinformatics }\end{array}$ & 265 & & \\
\hline $\begin{array}{l}\text { Emerald Emerging } \\
\text { Markets Case } \\
\text { Studies }\end{array}$ & 8 & $\begin{array}{l}\text { IFIP Advances in } \\
\text { Information and } \\
\text { Communication Technology }\end{array}$ & 257 & & \\
\hline $\begin{array}{l}\text { Journal of Business } \\
\text { Research }\end{array}$ & 8 & $\begin{array}{l}\text { Lecture notes on } \\
\text { mechanical engineering }\end{array}$ & 211 & & \\
\hline $\begin{array}{l}\text { Social Responsibility } \\
\text { Journal }\end{array}$ & 8 & Sustainability Switzerland & 210 & & \\
\hline $\begin{array}{l}\text { Acta Mathematica } \\
\text { Scientia }\end{array}$ & 6 & $\begin{array}{l}\text { ACM International } \\
\text { Conference Proceeding } \\
\text { Series }\end{array}$ & 209 & & \\
\hline $\begin{array}{l}\text { Competitiveness } \\
\text { Review }\end{array}$ & 6 & $\begin{array}{l}\text { Journal of Physics } \\
\text { Conference Series }\end{array}$ & 197 & & \\
\hline
\end{tabular}

\subsubsection{Author statistics}

Table 5 represents the most prominent authors who have published articles on the three different categories that have been identified for further analysis. The '...' depicted in the tables below represent a break in the data: certain information was included to depict important findings, and other information was left out because it did not add any insight to this paper.

David Romero has been identified as the only author to have published documents in both the SV and the 4IR categories. He has published two articles in the SV category: 'Green virtual enterprise breeding environments enabling the resolve framework' [15], and 'Green virtual enterprise breeding environments bag of assets management: A contribution to the sharing economy' [16]. Both were published by IFIP Advances in Information and Communication Technology, which can be seen as a strong connection with the application of technology in BSMs. He has published 37 documents in the 4IR category, most noticeably the following: 'A critical review of smart manufacturing \& Industry 4.0 maturity models: Implications for small and medium-sized enterprises (SMEs)' [17], and 'Social factory architecture: Social networking 
services and production scenarios through the social internet of things, services and people for the social operator 4.0' [18], which are also his two most cited articles. His research focus is on both the human and the social dimensions of technology. The research already conducted could most likely be transferable to the application of 4IR technologies to SV business practices.

Table 5: Top 10 authors by document count

\begin{tabular}{|c|c|c|c|c|c|}
\hline \multicolumn{2}{|c|}{ SV $(\{S V\})$} & \multicolumn{2}{|c|}{ 4IR } & \multicolumn{2}{|c|}{ Integrated concept $\left(\{S V\} \_4 I R\right\}$} \\
\hline Author & Documents & Author & Documents & Author & Documents \\
\hline Camilleri, M.A. & 7 & Rauch, E. & 66 & Corò, G. & 1 \\
\hline Markopoulos, E. & 5 & Zharinov, I.O. & 63 & Kim, K.J. & 1 \\
\hline Sen, S.K. & 5 & Shukalov, A.V. & 58 & Merma, Y.P.C. & 1 \\
\hline Vanharanta, H. & 5 & Zakoldaev, D.A. & 54 & Park, S.H. & 1 \\
\hline Chen, J.F. & 4 & Matt, D.T. & 52 & Park, S. & 1 \\
\hline Fraser, J. & 4 & Wuest, T. & 44 & Plechero, $M$. & 1 \\
\hline Li, S. & 4 & Telukdarie, A. & 39 & Shin, W.S. & 1 \\
\hline Ongsakul, V. & 4 & Ferrari, P. & 37 & Volpe, M. & 1 \\
\hline Yang, L. & 4 & Romero, D. & 37 & & \\
\hline Alberti, F.G. & 3 & Franke, J. & 36 & & \\
\hline$\ldots$ & $\ldots$ & & & & \\
\hline Romero, D. & 2 & & & & \\
\hline
\end{tabular}

\subsubsection{Country statistics}

Table 6 shows the top ten countries' scientific production for each category, which indicates the country of affiliation of the first author of each paper. The statistics for South Africa and those that produced documents for the integrated concept were added for context. As expected, most of the research is conducted in the United States, various European countries, and China. Scholars from developing and emerging countries have limited representation on this list. These statistics reiterate just how limiting the integration of these two fields of literature is: the United States is in the top three in both fields, but the concepts have not been integrated in any of the literature. Italy is the only country in the top 10 that has produced a paper on the integration of these concepts. South Korea is the top producer of literature on the integrated concepts; although late-starters in focusing on 4IR technologies, it is quickly closing the gap between itself and the European countries [19].

Table 6: Top 10 countries by number of documents

\begin{tabular}{|c|c|c|c|c|c|}
\hline \multicolumn{2}{|c|}{ SV $(\{S V\})$} & \multicolumn{2}{|c|}{$4 \mathrm{IR}$} & \multicolumn{2}{|c|}{$\begin{array}{c}\text { Integrated concept } \\
\left(\{S V\} \_4 I R\right\}\end{array}$} \\
\hline Country & Documents & Country & Documents & Country & Documents \\
\hline United States & 158 & Germany & 2671 & South Korea & 2 \\
\hline United Kingdom & 95 & Italy & 1669 & Italy & 1 \\
\hline China & 78 & United States & 1106 & Peru & 1 \\
\hline Italy & 56 & China & 1015 & & \\
\hline Australia & 45 & United Kingdom & 941 & & \\
\hline Spain & 40 & India & 914 & & \\
\hline India & 30 & Russian Federation & 861 & & \\
\hline Finland & 29 & Spain & 733 & & \\
\hline Germany & 29 & South Korea & 664 & & \\
\hline Netherlands & 29 & ... & $\ldots$ & & \\
\hline$\ldots$ & $\ldots$ & South Africa & 533 & & \\
\hline South Korea & 29 & $\ldots$ & $\ldots$ & & \\
\hline South Africa & 16 & Peru & 44 & & \\
\hline ... & $\ldots$ & & & & \\
\hline Peru & 3 & & & & \\
\hline
\end{tabular}

The country collaboration map for the SV and 4IR categories was constructed using the Bibliometrix package [12]. This indicates that a large amount of collaboration is taking place, especially with regard to 4IR research. 


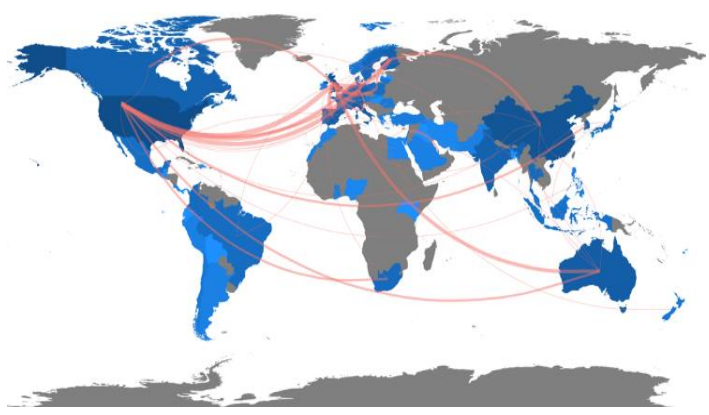

Figure 4: SV collaboration map

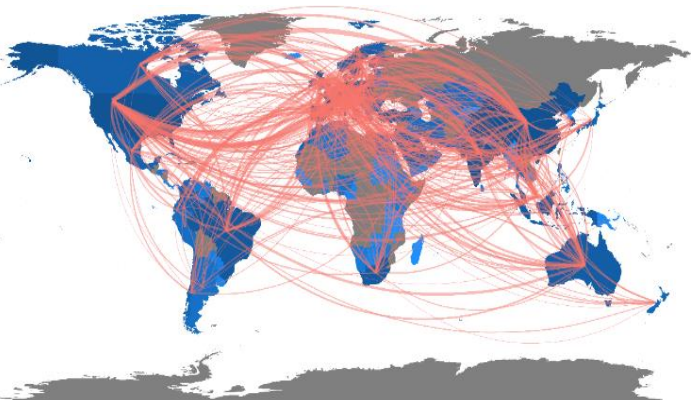

Figure 5: 4IR collaboration map

\subsubsection{Subject areas of study}

Figure 6 depicts the most common subject areas of SV and 4IR and the three areas that pertain to the integrated concept. Business, management, and accounting are the most common subject areas that overlap all categories. Out of the ten subject areas identified, six pertain to the science field, two to the commerce field, and only one (social sciences) to the humanities field. Interestingly, the integrated concept is balanced in combining the science, commerce, and social studies fields.

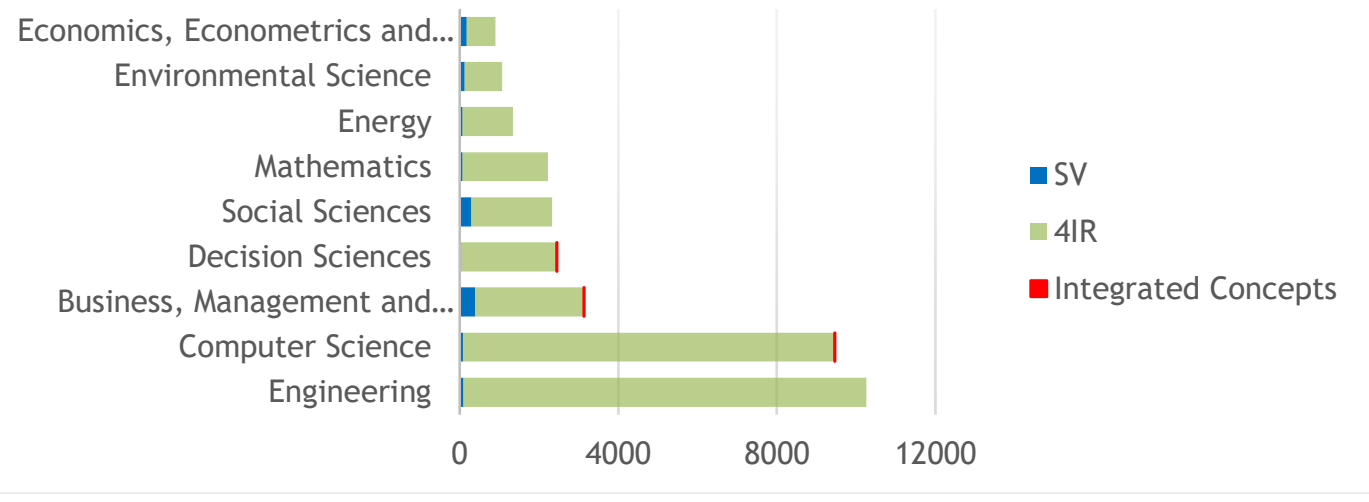

Figure 6: Top common subject areas

\subsubsection{Thematic map}

The thematic map for SV and 4IR was constructed to gain insight into the themes currently being discussed in the literature. The thematic map was constructed using the R-Bibliometrix package [12]. Themes in the upper-right quadrant are known as the 'motor themes' (high centrality and density), which means that they are developed and are important to the research field. Themes in the upper-left quadrant are known as the 'high developed and isolated themes/niche themes'. They have well-developed internal links (high density) but unimportant external links, and so are of only limited importance for the field (low centrality). Themes in the lower-left quadrant are known as 'emerging or declining themes' [20]. They have both low centrality and density, meaning that they are weakly developed and marginal. Themes in the lower-right quadrant are known as 'basic and transversal themes'. They are characterised by high centrality and low density. These themes are important to a research field, and concern general topics that span to the different research areas of the field. 


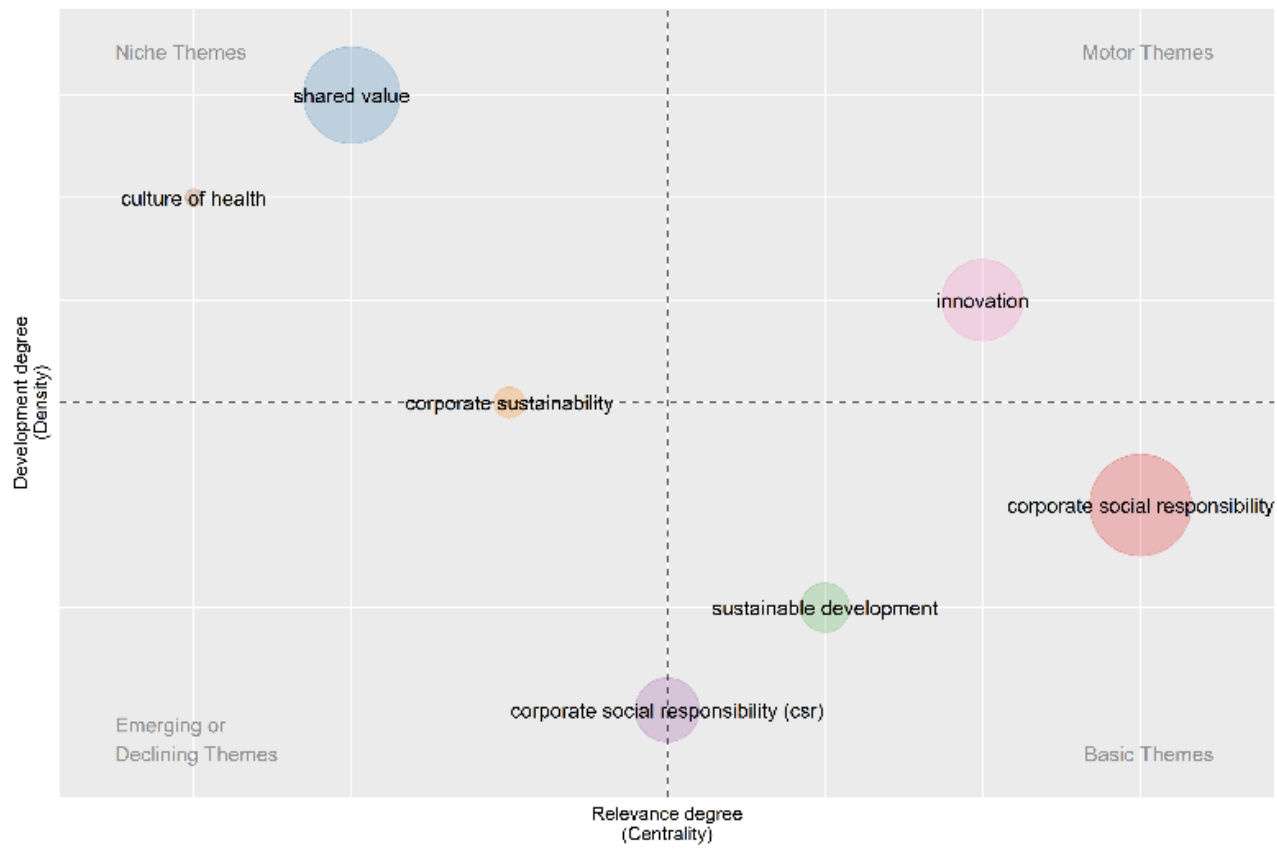

Figure 7: SV (\{SV\}) Thematic Map

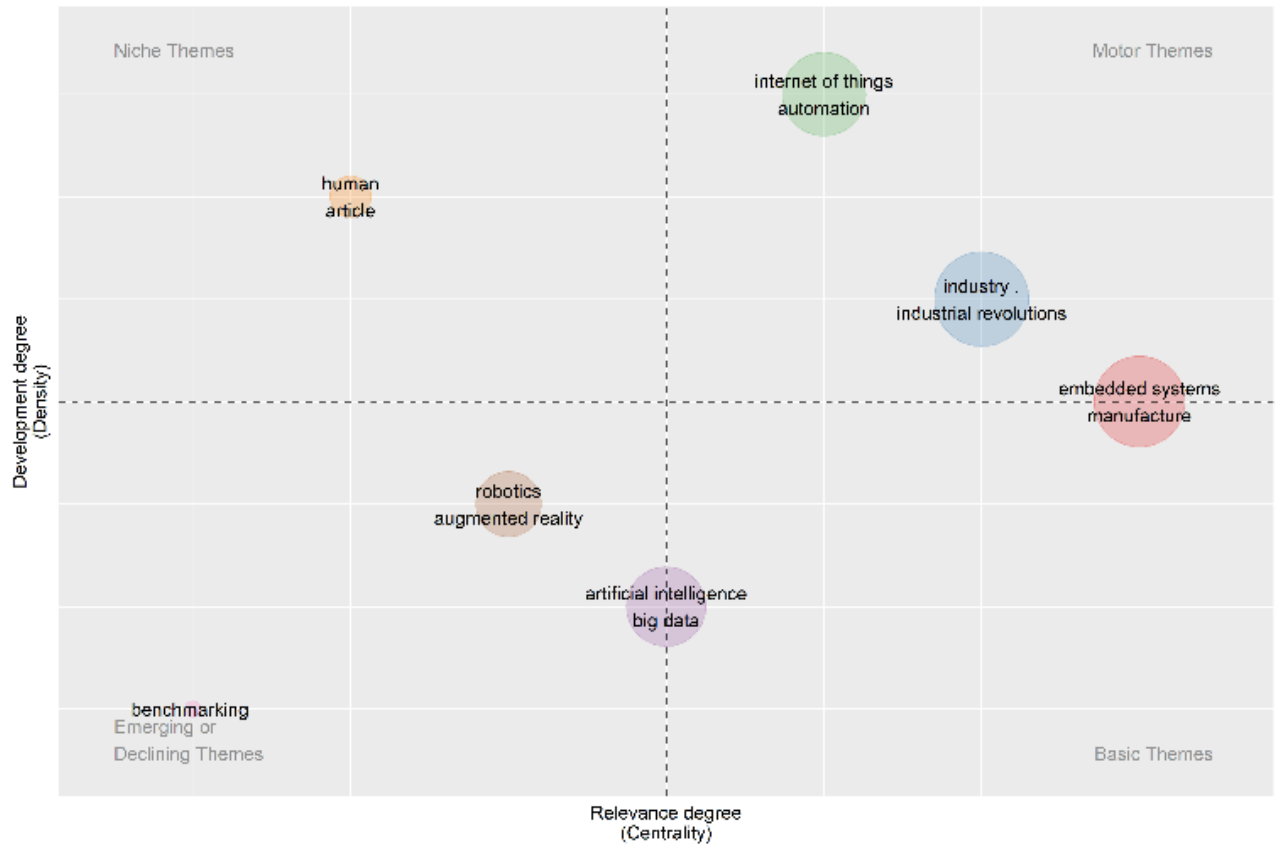

Figure 8: 4IR Thematic Map

It is interesting to notice in Figure 7 that the motor theme includes innovation, which can be seen as new methods and ideas that are being incorporated into these SV business practices. In Figure 8, the strong technical themes present themselves.

\subsubsection{Keywords}

The most frequent authors' keywords for the various categories are described in Table 7. Noticeably, the only keyword that presents itself in the SV, 4IR, and integrated concept categories is 'sustainability'.

The keyword 'creating shared value' occurred only twice in the category of $4 \mathrm{IR}$, which is miniscule considering that 17891 documents were identified. 'Circular economy' presented itself 120 times, 
indicating that there is a definite interest, although small, in BSMs and the incorporation of 4IR technologies.

'Sustainable innovation' occurred in SV and 4IR, with four and three entries respectively. The fact that it occurred more often in the SV dataset (825 documents) than in the 4IR dataset (17 891 documents) indicated the lack of literature that was focused on the innovation of sustainable technology and its implementation when considering the 4IR. The terms 'technology' and 'digital transformation' occurred in the SV dataset only four times and in Industry 4.0 only twice. This indicates a real lack of research into technology applications in the SV literature, which points to a huge gap and an opportunity for research.

Table 7: Authors' keywords

\begin{tabular}{|c|c|c|c|c|c|}
\hline \multicolumn{2}{|c|}{ SV $(\{S V\})$} & \multicolumn{2}{|l|}{ 4IR } & \multicolumn{2}{|c|}{ Integrated concept $\left(\{S V\} \_4 I R\right\}$} \\
\hline Word & Occurrences & Word & Occurrences & Word & Occurrences \\
\hline Shared value & 218 & Industry 4.0 & 7022 & $\begin{array}{l}\text { Creating shared } \\
\text { value }\end{array}$ & 2 \\
\hline $\begin{array}{l}\text { Corporate social } \\
\text { responsibility }\end{array}$ & 97 & Internet of Things & 882 & Industry 4.0 & 2 \\
\hline $\begin{array}{l}\text { Creating shared } \\
\text { value }\end{array}$ & 75 & IOT & 547 & $\begin{array}{l}\text { Fourth Industrial } \\
\text { Revolution }\end{array}$ & 1 \\
\hline Sustainability & 61 & Smart manufacturing & 512 & Sixth Industry & 1 \\
\hline $\begin{array}{l}\text { Meromorphic } \\
\text { function }\end{array}$ & 38 & Big Data & 478 & Agriculture & 1 \\
\hline CSR & 24 & Machine learning & 463 & Convergence & 1 \\
\hline Innovation & 22 & Artificial intelligence & 461 & $\begin{array}{l}\text { Digital } \\
\text { technologies }\end{array}$ & 1 \\
\hline $\begin{array}{l}\text { Sustainable } \\
\text { development }\end{array}$ & 22 & $\begin{array}{l}\text { Cyber-physical } \\
\text { systems }\end{array}$ & 414 & $\begin{array}{l}\text { Digital } \\
\text { transformation }\end{array}$ & 1 \\
\hline Strategy & 19 & $\begin{array}{l}\text { Fourth Industrial } \\
\text { Revolution }\end{array}$ & 396 & $\begin{array}{l}\text { Innovation } \\
\text { management }\end{array}$ & 1 \\
\hline Uniqueness & 16 & Smart factory & 382 & $\begin{array}{l}\text { Intelligent } \\
\text { information } \\
\text { technology }\end{array}$ & 1 \\
\hline Normal family & 15 & Digitalisation & 375 & ISO 26000 & 1 \\
\hline $\begin{array}{l}\text { Social } \\
\text { responsibility }\end{array}$ & 15 & Digital twin & 363 & $\begin{array}{l}\text { Management } \\
\text { quality }\end{array}$ & 1 \\
\hline Value creation & 15 & $\begin{array}{l}\text { Digital } \\
\text { transformation }\end{array}$ & 288 & $\begin{array}{l}\text { Maturity } \\
\text { assessment }\end{array}$ & 1 \\
\hline Business model & 13 & Manufacturing & 270 & Mining & 1 \\
\hline $\begin{array}{l}\text { Corporate social } \\
\text { responsibility } \\
\text { (CSR) }\end{array}$ & 13 & Cloud computing & 259 & $\begin{array}{l}\text { Multi-way flow of } \\
\text { quality } \\
\text { management }\end{array}$ & 1 \\
\hline $\begin{array}{l}\text { Corporate } \\
\text { sustainability }\end{array}$ & 12 & Sustainability & 254 & SMEs & 1 \\
\hline $\begin{array}{l}\text { Creating shared } \\
\text { value (CSV) }\end{array}$ & 12 & Blockchain & 250 & $\begin{array}{l}\text { Social } \\
\text { responsibility }\end{array}$ & 1 \\
\hline Entrepreneurship & 12 & Automation & 241 & Sustainability & 1 \\
\hline Values & 12 & $\begin{array}{l}\text { Industrial Internet of } \\
\text { Things }\end{array}$ & 237 & & \\
\hline Ethics & 11 & Augmented reality & 233 & & \\
\hline
\end{tabular}

\subsection{Integrated concept descriptive analytics}

As mentioned previously, this article aims to assess the literature at the intersection between SV business concepts and 4IR. This section highlights key findings in the bibliometric analysis of the literature found in the search category $\{$ SV $\} \_4 I R$ for impact, prominence, and further opportunity identification.

There are four documents in this category, which will be discussed briefly in the next section. A concise citation analysis of these articles will follow.

\subsubsection{Discussion of content}

A study on convergence of intelligent information technology of 6th Industry for sustainability

This article examines linked cases and research to demonstrate the limits of South Korea's agricultural and sixth industry, and it proposes possibilities for creating shared value to address rural difficulties. It emphasises themes such as mutual growth, win-win cooperation, and the Fourth Industrial Revolution [21]. 


\section{Veneto Region}

This research focuses on linking the data on the adoption of digital technologies with firms' performances and employment behaviour, with a discussion of the main features that distinguish these firms. The research indicated that the firms adopting 14.0 technologies are not only characterised by workers with higher competences and educational profiles, but are also those showing higher productivity, employment growth, and a shared value strategy [22].

Assessing a social responsibility model for sustainable company growth in the Fourth Industrial Revolution This paper aims to present a revised social responsibility (SR) model as an evaluation tool for CSR performance for sustainable organisational growth in the era of the 4IR. It includes a new SR model for sustainable development in the 4IR that incorporates the concepts of management quality (MQ), quality responsibility $(\mathrm{QR})$, creating shared value (CSV), social value, and open data and open quality management [23].

An innovation management approach for the digital transformation of industries maturity assessment: Case studies in the Peruvian mining

This research was proposed as part of the 29th International Conference of the International Association for Management of Technology (Towards the Digital World and Industry X.0). The aim of this work is to "propose a Maturity Model for Digital Transformation of Industries according to the principles of Innovation Management and its respective applications in a specific sector" [24](focused on mining case studies). Key process areas for the maturity model include resource efficiency, operational efficiency, and shared value [24].

\subsubsection{Citation analysis}

Given the timeline and rate of literature output, it is understandable that citation counts are still low. The article 'Assessing a social responsibility model for sustainable company growth in the Fourth Industrial Revolution' [23] is the only one with citations (2), being cited in papers about other BSMs - including a paper entitled 'Industry 4.0 and sustainable development: A systematic mapping of triple bottom line, circular economy and sustainable business models perspectives' [25]. This could indicate that some of the other BSM 4IR technology applications might be transferable to that of the shared value concept.

\section{DISCUSSION}

A basic bibliometric study was done to evaluate the current research being conducted on 4IR and CSV, and the extent of either integration or disconnection between the concepts of the 4IR and CSV. It was confirmed through multiple different figures and data that there is a disconnect between these two bodies of literature.

As only four documents have been written on the integration of these two concepts, the application of 4IR technological interventions in shared value business practices have only begun, and so have not yet evolved. It has only been seen that a variety of literature has been written about other BSMs and the integration of 4IR technologies in these movements. It would take a deeper analysis of these other BSMs to deduce the evolution of the technological interventions. The external factors that have driven the increased amount of literature and the expansion of academic work in the fields of 4IR and BSMs have largely been the development goals of the UN [7] and the radical increase in 4IR technologies in the world today. Since there is still a disconnect in the literature about the integration of these concepts, the research suggests that there is currently no underlying framework for the use of 4IR technology specifically in CSV. As mentioned before, there are indicators to suggest that this type of framework does exist for other BSMs.

The direction of future research in this domain includes the development not only of theoretical approaches but also of practical tools and approaches for business that are applicable to ensuring the increase of sustainable practices in the workplace. This could be done by evaluating other tools and approaches related to other BSMs and applying them to the CSV concept.

\section{CONCLUSION}

The overall conclusion of this analysis is that there is a clear gap, and thus an opportunity for research that jointly analyses the shared value BSM and the 4IR. The short time line renders the field novel, and the lack of a comprehensive coverage of various parts of the world outside developed countries leaves significant opportunity for research outside that region to assess what these concepts are in their contexts, and their 
implications. The fact that only four documents apply to the criteria set out in this paper can confirm that there is significant potential for future research on this subject.

In addition, the subject areas and keywords indicate that there is a high possibility for parallels with research that focuses only on the sustainability aspect of shared value and 4IR, as both ideas are linked to this concept. An increase in scientific production can be expected as the study on these topics becomes more relevant.

By broadening the scope to other BSMs, significantly more literature has been written about the Circular Economy movement. There is thus also huge potential for the transfer of knowledge of the application of current 4IR solutions already being implemented in BSMs.

In conclusion, this paper highlights the need for the expansion of knowledge concerned with shared value business practices and 4IR technologies. These findings support the need for further analysis and synthesis of the existing literature to identify specific gaps and needs in the field to ensure a meaningful and applicable research output.

\section{REFERENCES}

[1] WEF, "Fourth Industrial Revolution | World Economic Forum," 2019. https://www.weforum.org/focus/fourthindustrial-revolution (accessed Mar. 30, 2020).

[2] J. O. Effoduh, "The Fourth Industrial Revolution by Klaus Schwab,” The Transnational Human Rights Review, vol. 3, 2016. Accessed: Apr. 27, 2021. [Online]. Available: http://digitalcommons.osgoode.yorku.ca/thr/vol3/iss1/4.

[3] M. Piccarozzi, B. Aquilani, and C. Gatti, "Industry 4.0 in management studies: A systematic literature review," Sustainability, vol. 10, no. 10, pp. 1-24, 2018, doi: 10.3390/su10103821.

[4] K. Schwab, The Fourth Industrial Revolution. World Economic Forum, 2016.

[5] M. R. Kramer and M. W. Pfitzer, "The ecosystem of shared value," Harvard Bussiness Review, vol. 10, pp. 80-89, 2016, Accessed: Mar. 10, 2021. [Online]. Available: https://hbr.org/2016/10/the-ecosystem-of-shared-value.

[6] M. Porter and M. Kramer, "Creating shared value (CSV)," Journal of direct, data and digital marketing practice, vol. 12, no. 4, pp. 380, 2011.

[7] G. Tóth, "Circular economy and its comparison with 14 other business sustainability movements," Resources, vol. 8 no. 4, pp. 159, 2019, doi: $10.3390 /$ resources 8040159 .

[8] D. Gil-Doménech, J. Berbegal-Mirabent, and J. M. Merigó, "STEM education: A bibliometric overview," in Advances in Intelligent Systems and Computing, vol. 894, T. Ditzinger, Ed. Springer Verlag, 2020, pp. 193-205, doi: 10.1007/978-3-030-15413-4_15.

[9] G. Soni, S. Kumar, P. Singh, B. L. Dey, and M. Dora, "Technological forecasting \& social change technological interventions in social business: Mapping current research and establishing future research agenda," Technological Forecasting \& Social Change, vol. 169, no. April, p. 3-15, 2021, doi: 10.1016/j.techfore.2021.120818.

[10] I. Zupic and T. Ĉater, "Bibliometric methods in management and organization," Organizational Research Methods, vol. 18, no. 3, pp. 429-472, 2015, doi: 10.1177/1094428114562629.

[11] J. F. Burnham, "Scopus database: A review," Biomedical Digital Libraries, vol. 3. BioMed Central, p. 1, 2006, doi: 10.1186/1742-5581-3-1.

[12] M. Aria and C. Cuccurullo, "Bibliometrix: An R-tool for comprehensive science mapping analysis," Journal of Informetrics, vol. 11, no. 4, pp. 959-975, 2017, doi: 10.1016/j.joi.2017.08.007.

[13] Y. Zhang, S. Pu, X. Lv, Y. Gao, and L. Ge, "Global trends and prospects in microplastics research: A bibliometric analysis," Journal of Hazardous Materials, vol. 400, 123110, 2020, doi: 10.1016/j.jhazmat.2020.123110.

[14] ICIC-ELB, ICIC Express Letters, Part B: Applications, 2010. http: //www.icicelb.org/ (accessed Jun. 21, 2021).

[15] D. Romero, O. Noran, and P. Bernus, "Green virtual enterprise breeding environments enabling the Resolve framework," in IFIP Advances in Information and Communication Technology, 2017, vol. 506, pp. 603-613, doi: 10.1007/978-3-319-65151-4_53.

[16] D. Romero, O. Noran, and H. Afsarmanesh, “Green virtual enterprise breeding environments bag of assets management: A contribution to the sharing economy," IFIP Advances in Information and Communication Technology, vol. 463, pp. 439-447, 2015, doi: 10.1007/978-3-319-24141-8_40.

[17] S. Mittal, M. A. Khan, D. Romero, and T. Wuest, "A critical review of smart manufacturing \& Industry 4.0 maturity models: Implications for small and medium-sized enterprises (SMEs)," Journal of Manufacturing Systems, vol. 49, pp. 194-214, 2018, doi: 10.1016/j.jmsy.2018.10.005.

[18] D. Romero, T. Wuest, J. Stahre, and D. Gorecky, "Social factory architecture: Social networking services and production scenarios through the social internet of things, services and people for the Social Operator 4.0," IFIP Advances in Information and Communication Technology, vol. 513, pp. 265-273, 2017, doi: 10.1007/978-3-31966923-6_31.

[19] P. N. Funwie, "The 4th Industrial Revolution: International relations and policy: Case of S. Korea and China," The 4th Industrial Revolution and International Affairs, pp, 3-23, 2019.

[20] V. Della Corte, G. Del Gaudio, F. Sepe, and F. Sciarelli, "Sustainable tourism in the open innovation realm: A bibliometric analysis," Sustainability, vol. 11, no. 21, pp. 1-18, 2019, doi: 10.3390/su11216114.

[21] S. Park, "A study on convergence of intelligent information technology of 6th Industry for sustainability," ICIC Express Letters, Part B: Applications, vol. 11, no. 9, pp. 823-829, 2020, doi: 10.24507/icicelb.11.09.823. 
[22] G. Corò, M. Plechero, and M. Volpe, "Driving factors and effects on SMEs of the adoption of Industry 4.0 technologies: An investigation of Veneto Region,” L'industria, vol. 41, no. 2, pp. 215-237, 2020, doi: 10.1430/97563.

[23] S. Hyun Park, W. Seon Shin, and K. Jae Kim, "Assessing a social responsibility model for sustainable company growth in the Fourth Industrial Revolution," International Journal of Quality and Service Sciences, vol. 11, no. 3, pp. 334-345, 2019 doi: 10.1108/IJQSS-11-2017-0108.

[24] Y. P. C. Merma, "An innovation management approach for the digital transformation of industries maturity assessment: Case studies in the Peruvian mining," in Towards the Digital World and Industry X.O - Proceedings of the 29th International Conference of the International Association for Management of Technology, IAMOT 2020, Pretorius, L., 2020, pp. 641-652.

[25] I. S. Khan, M. O. Ahmad, and J. Majava, "Industry 4.0 and sustainable development: A systematic mapping of triple bottom line, circular economy and sustainable business models perspectives," Journal of Cleaner Production, vol. 297, 126655, 2021, doi: 10.1016/j.jclepro.2021.126655. 